\title{
HUBUNGAN PERSONAL HYGIENE SAAT MENSTRUASI DENGAN KEJADIAN PRURITUS VULVAE PADA REMAJA DI SMA NEGERI 7 MANADO
}

\author{
Lingkan G. E. K. Pandelaki', Sefti Rompas², Hendro Bidjuni²
}

1. Mahasiswa Program Studi Ilmu Keperawatan Fakultas Kedokteran

Universitas Sam Ratulangi

2. Program Studi Ilmu Keperawatan Fakultas Kedokteran

Universitas Sam Ratulangi

Email : pandelakilingkan@gmail.com

\begin{abstract}
Abstrack
Background : Cleanliness of genetal areas (Personal Hygiene) especially when menstruation is often neglected by adolescents, if they do not maintain genetal hygiene properly, then in a moist condition, fungi and bacteria that are in the genetal area will flourish, causing itching (Pruritus Vulvae) and infection in the area. The purpose of this research was to determine the corelation between Personal Hygiene and the incidence of pruritus vulvae in adolescents in Public Senior High School 7 Manado. This research method used a descriptive analytic research design with Cross Sectional Study approach. A sample of 148 respondents were obtained using the Simple Rondom Sampling technique. The test results showed the relationship between Personal Hygiene During Menstruation with the incidence of Pruritus Vulvae with the incidence of pruritus vulvae in adolescents in the moderate category of 65 respondents (66.3\%). The conclusion is that there is a relationship between Personal Hygiene and the incidence of pruritus vulvae in adolescents in Manado's 7th Middle School.
\end{abstract}

Keywords: Personal Hygiene, Pruritus Vulvae, Menstruation.

\begin{abstract}
Abstrak
Latar Belakang Kebersihan daerah genetalia (Personal Hygiene) terutama ketika menstruasi sering diabaikan oleh remaja, jika tidak menjaga kebersihan genetalia dengan benar, maka dalam keadaan lembab, jamur dan bakteri yang berada di daerah genetalia akan tumbuh subur sehingga menyebabkan rasa gatal (Pruritus Vulvae) dan infeksi pada daerah tersebut. Tujuan untuk mengetahui hubungan Personal Hygiene dengan Kejadian Pruritus Vulvae Pada Remaja di Sekolah Menengah Atas Negeri 7 Manado. Metode penelitian ini menggunakan desain penelitian yaitu Deskriptif Analitik dengan pendekatan Cross Sectional Study. Sampel berjumlah 148 responden yang didapat dengan menggunakan tehnik Simple Rondom Sampling. Hasil uji didapatkan hasil hubungan antara Personal Hygiene Saat Menstruasi dengan Kejadian Pruritus Vulvae dengan kejadian pruritus vulvae pada remaja dalam kategori sedang sebanyak 65 orang responden (66,3\%).Kesimpulan ada hubungan antara Personal Hygiene dengan Kejadian Pruritus Vulvae Pada Remaja di Sekolah Menegah Atas Negeri 7 Manado.

Kata kunci : Personal Hygiene, Pruritus Vulvae, Menstruasi.
\end{abstract}




\section{PENDAHULUAN}

Kesehatan reproduksi adalah keadaan sejahtera fisik, mental dan sosial secara utuh, yang tidak semata-mata bebas dari penyakit atau kecacatan dalam semua hal yang berkaitan dengan sistem reproduksi serta fungsi dan prosesnya (Depkes, 2001). Remaja merupakan masa transisi dari anak-anak menjadi dewasa, pada masa remaja terjadi perubahan hormonal, fisik, psikologis maupun sosial. Dimana kondisi tersebut dimaknai dengan kondisi pubertas. Salah satu tanda pubertas pada remaja putri yaitu terjadinya menstruasi (Batubara, 2010).

Hasil survei yang di lakukan World Health Organization (WHO) di beberapa negara menyebutkan remaja putri berusia 10-14 tahun mempunyai permasalahan terhadap reproduksinya salah satunya pruritus vulvae. Dengan adanya peristiwa ini menuntut remaja putri mampu merawat organ reproduksinya dengan baik (Prawirohardjo, 2009). Kebersihan daerah genetalia terutama ketika menstruasi sering diabaikan oleh remaja, jika tidak menjaga kebersihan genetalia dengan benar, maka dalam keadaan lembab, jamur dan bakteri yang berada di daerah genetalia akan tumbuh subur sehingga menyebabkan rasa gatal dan infeksi pada daerah tersebut.

Personal hygiene menstruasi adalah perilaku yang berkaitan dengan tindakan untuk memelihara kesehatan dan upaya menjaga kebersihan pada daerah kewanitaan saat menstruasi, perilaku tersebut mencakup: menjaga genetalia, seperti mencucinya dengan dengan air bersih, menggunakan celana yang mudah menyerap keringat, mengganti celana dalam minimal dua kali sehari untuk menjaga vagina dari kelembapan yang berlebihan, sering mengganti pembalut, pemakaian pembalut tidak boleh lebih dari 6 jam diganti 4-5 kali atau setiap setelah mandi, buang air kecil dan buang air besar. Apabila di permukaan pembalut telah ada gumpalan darah, dan mandi dua kali sekali (Pribakti, 2008).
Gangguan pada wanita saat menstruasi sangatlah luas, salah satunya adalah iritasi atau rasa gatal di sekitar vulva dan lubang vagina (secara kedokteran disebut Pruritus vulvae). Pruritus vulvae adalah gangguan yang ditandai dengan sensasi gatal parah dari alat kelamin eksternal perempuan. Pruritus vulvae biasanya terjadi pada malam hari. Ketika sedang tidur kemungkinan menggaruk daerah tersebut tanpa menyadarinya dan dapat menyebabkan beberapa memar dan berdarah. Pada tahap selanjutnya Pruritus vulvae mempengaruhi kehidupan sosial seorang wanita (Wolff dan Johnson, 2009).

Berdasarkan data dari Kementrian Kesehatan (2017) di Indonesia menunjukan bahwa sebanyak 5,2 juta remaja putri yang sering mengalami keluhan setelah menstruasi akibat tidak menjaga kebersihannya yaitu pruritus vulvae ditandai dengan adanya sensasi gatal pada alat kelamin wanita (Kemenkes RI, 2017). Dan berdasarkan data statistic di Indonesia dari 69.4 juta jiwa remaja yang ada di Indonesia terdapat sebanyak 63 juta remaja berperilaku hygiene sangat buruk. Seperti kurangnya tindakan merawat kesehatan organ reproduksi ketika mengalami menstruasi. Perilaku yang kurang dalam merawat daerah kewanitaan sejumlah $30 \%$ yang diakibatkan lingkungan yang buruk atau tidak sehat dan $70 \%$ di akibatkan oleh penggunaan pembalut yang kurang tepat ketika menstruasi. (Riskesdas, 2016).

Berdasarkan pengambilan data awal yang di lakukan di SMA N 7 Manado, diketahui jumlah siswi berjumlah 773 . Telah dilakukan wawancara awal terhadap 15 orang siswi, didapati 15 siswi tersebut mengalami pruritus vulvae ketika menstruasi. Ditandai dengan 15 siswi mengalami gatal di daerah kewanitaan, 15 siswi mengalami merah pada vagina saat mengaruk, 15 siswi mengalami keputihan, 7 siswi mengalami rasa terbakar pada vagina saat mengaruk, dan 3 siswi megalami benjolan berisi air pada vagina ketika gatal. 10 siswi mengalami pruritus vulvae diakibatkan karena Pesonal Hygiene 
yang buruk, sedangkan 5 siswi lainnya memiliki Personal Hygiene yang baik namun mengalami pruritus vulvae.

Berdasarkan fenomena yang ada bahwa siswi di SMA N 7 Manado ada yang memiliki pruritus vulvae di karenakan belum memiliki personal hygiene yang baik, dan di sulawesi utara belum pernah ada yang meneliti tentang pruritus vulvae dengan personal hygiene, dan penelitian sebelumnya memiliki jumlah populasi lebih sedikit dari penelitian ini maka peneliti tertarik untuk melakukan penelitian yang bertujuan untuk mengetahui "Hubungan Personal Hygiene Saat Mensturasi dengan Kejadian Pruritus Vulvae Pada Remaja di SMA N 7 Manado".

\section{METODE PENELITIAN}

Penelitian ini termasuk dalam jenis penelitian kuantitatif dengan menggunakan metode penelitian survei analitik untuk menganalisis hubungan antara 2 (dua) variabel yaitu variabel independen dan variabel dependen. Dalam penelitian ini menggunakan desain penelitian cross sectional. Penelitian ini dilaksanakan di SMA Negeri 7 Manado pada tanggal bulan Desember 2019. Populasi penelitian ini adalah seluruh kelas X jumlah 233. Pengambilan sampel menggunakan teknik Simple random sampling dengan rumus slovin maka didapatkan jumlah sampel 148 remaja. Instrumen penelitian yang digunakan untuk mengukur variabel Personal hygiene menggunakan kuesioner yang digunakan sebelumnya oleh Sulaikha (2018), Kuesioner ini terdiri dari dari 16 pertanyaan dengan menggunakan penilaian Selalu (SL), Sering (SR), Kadang-kadang (KK), dan Tidak pernah (TP). Pada pernyataan positif, nilai bergerak dari empat sampai satu dimana pilihan selalu diberi skor 4, sering diberi skor 3, kadangkadang diberi skor 2, dan tidak pernah diberi skor 1 . Sebaliknya pada pernyataan negatif, nilai bergerak dari satu sampai empat dimana pilihan selalu diberi skor 1, sering diberi skor 2, kadang-kadang diberi skor 3, dan tidak pernah diberi skor 4 ..
Pengukuran Pruritus Vulvae menggunakan kuesioner yang digunakan sebelumnya oleh Sulaikha (2018). Kuesioner ini terdiri dari dari 10 pertanyaan dengan menggunakan penilaian ya, dan tidak. Isian dibagi dalam 2 kategori yaitu 1 untuk jawaban Ya dan 0 untuk jawaban tidak.

Analisa yang digunakan adalah hasil tabulasi silang. Untuk menguji hipotesa dilakukan analisa statistik dengan uji Chi - square pada tingkat kemaknaan 95\% (P.Value < 0,05). Melalui perhitungan chi-square selanjutnya ditarik kesimpulan, bila nilai $\mathrm{P}$ lebih kecil dari nilai $\alpha(0,05)$, maka $\mathrm{H} 0$ ditolak dan Ha diterima, yang menunjukkan ada hubungan personal hygiene saat menstruasi dengan kejadian pruritus vulvae pada remaja.

Penelitian telah dilakukan dengan standar etika penelitian bertujuan untuk menjaga kerahasiaan identitas responden (Confidentially), memberikan lembar persetujuan menjadi responden (Informed consent) dan tidak mencantumkan nama responden hanya menggunakan inisial (Anonymity) Penelitian ini telah mendapat izin dari SMA Negeri 7 Manado dengan dilandasi oleh surat izin penelitiaan No. 699/D.P.2.2S.SMA-7/2019.

\section{HASIL dan PEMBAHASAN}

1. Karakteristik Responden

Tabel 1. Distribusi Responden Berdasarkan Usia

\begin{tabular}{ccc}
\hline Usia & $\mathbf{f}$ & \% \\
\hline 13 Tahun & 8 & 5,4 \\
14 Tahun & 26 & 17,6 \\
15 Tahun & 114 & 77,0 \\
\hline Total & $\mathbf{1 4 8}$ & $\mathbf{1 0 0}$ \\
\hline
\end{tabular}

Sumber : Data Primer 2019

Hasil penelitian menunjukkan bahwa mayoritas responden berusia 15 tahun $(77,0 \%)$. Pada penelitian ini, umur remaja putri berkisar antara 13-15 tahun dimana usia tersebut termasuk kategori masa remaja awal. Remaja awal mengalami perkembangan psikologis dimulai dari sikap penerimaan pada perubahan kondisi 
fisik, berkembangnya cara berpikir namun bersikap overestimate. Pada tahap ini remaja menganggap hygiene menstruasi tidaklah begitu penting, sehingga mereka tidak mencari tahu tentang hal-hal yang berkaitan dengan kesehatan reproduksi mereka (Hubaedah, 2019).

\section{Analisa Univariat}

Tabel 2. Distribusi Responden

Berdasarkan Personal Hygiene \& Pruritus

Vulvae

\begin{tabular}{cccccc}
\hline Personal Hygiene & $\mathbf{f}$ & $\boldsymbol{\%}$ & Pruritus Vulvae & $\mathbf{f}$ & \% \\
\hline Baik & 98 & 66,2 & Ringan & 36 & 24,3 \\
Cukup & 34 & 23,0 & Sedang & 90 & 60,8 \\
Kurang & 16 & 10,8 & Berat & 22 & 14,9 \\
& & & & & \\
\hline Total & $\mathbf{1 4 8}$ & $\mathbf{1 0 0}$ & Total & $\mathbf{1 4 8}$ & $\mathbf{1 0 0}$ \\
& & & & & \\
\hline
\end{tabular}

Sumber : Data Primer 2019

Tabel di atas pada bagian Personal Hygiene menunjukkan bahwa mayoritas responden mayoritas memiliki Personal Hygiene yang baik $(66,2 \%)$ Hal ini sejalan dengan penelitian Rosyid \& Mukhoirotin (2017) yang berjudul Hubungan Perilaku Personal Hygiene Saat Menstruasi Dengan Kejadian Pruritus Vulvae dengan jumlah sampel 83 responden yang personal hygienenya mayoritas dalam kategori yang baik. Pada penelitian ini remaja putri ada yang memiliki personal hygiene yang baik, cukup, dan kurang. Perilaku remaja mengenai kebersihan diri (personal hygiene) bisa di pengaruhi karena remaja ada belum mengetahui masalah personal hygiene secara benar dan remaja menganggap perilaku personal hygiene itu hal yang biasa serta belum mengetahui dampak negatif dari perilaku personal hygiene yang salah. Perilaku itu sendiri merupakan tindakan yang dapat diamati dan mempunyai frekuensi spesifik, durasi dan tujuan baik disadari maupun tidak disadari bahwa interaksi tersebut amat kompleks sehingga kadang-kadang kita tidak sempat memikirkan penyebab seseorang menerapkan perilaku tertentu (Wawan dan Dewi, 2010). 


\section{Analisa Bivariat}

Tabel 3. Hubungan Personal Hygiene dengan Pruritus Vulvae pada Remaja remaja tentang personal hygiene menstruasi dengan memberikan helath

\begin{tabular}{|c|c|c|c|c|c|c|c|c|c|}
\hline \multirow{3}{*}{$\begin{array}{c}\text { Personal } \\
\text { Hygiene }\end{array}$} & \multicolumn{8}{|c|}{ Pruritus Vulvae } & \multirow{3}{*}{$\rho$} \\
\hline & \multicolumn{2}{|c|}{ Ringan } & \multicolumn{2}{|c|}{ Sedang } & \multicolumn{2}{|c|}{ Berat } & \multicolumn{2}{|c|}{ Total } & \\
\hline & $\mathrm{f}$ & $\%$ & $\mathrm{f}$ & $\%$ & $f$ & $\%$ & $\mathrm{f}$ & $\%$ & \\
\hline Baik & 31 & 31,6 & 65 & 66,3 & 2 & 2,0 & 98 & 100,0 & \\
\hline Cukup & 4 & 11,8 & 22 & 64,7 & 8 & 23,5 & 34 & 100,0 & 0,000 \\
\hline Kurang & 1 & 6,3 & 3 & 18,8 & 12 & 75,0 & 16 & 100,0 & \\
\hline Total & 36 & 24,3 & 90 & 60,8 & 22 & 14,9 & 148 & 100,0 & \\
\hline
\end{tabular}

Sumber : Data Primer 2019

Berdasarkan hasil penelitian terhadap 148 responden di dapatkan hasil hubungan antara Personal Hygiene Saat Menstruasi dengan Kejadian Pruritus Vulvae dengan kejadian pruritus vulvae pada remaja dalam kategori sedang sebanyak $65(66,3 \%)$ responden. Dengan hasil uji statistik di peroleh nilai $\rho=0,000$ maka dapat disimpulkan bahwa ada hubungan antara Personal Hygiene Saat Menstruasi dengan Kejadian Pruritus Vulvae. Hal ini menandakan bahwa pruritus vulvae pada siswi di SMA N 7 Manado masih dalam keadaan sedang yang berarti belum terlalu berat, hal ini di karenakan personal hygiene yang di miliki oleh remaja.

Tingginya pengetahuan tentang kesehatan organ reproduksi wanita, tidak menjamin mempunyai perilaku yang baik untuk meningkatkan status kesehatannya. Hal ini di buktikan dengan hasil penelitian di dapatkan masih ada responden yang memiliki personal hygiene yang kurang sehingga memiliki pruritus vulvae dalam kategori berat sebanyak 12 responden $(75,0 \%)$.

Personal hygiene saat menstruasi merupakan perilaku yang dapat mempengaruhi kejadian pruritus vulvae. Kesadaran remaja putri terhadap perilaku tersebut harus di tingkatkan dengan meningkatkan pengetahuan yang di miliki education personal hygiene secara benar (Wawan \& Dewi, 2010).

Banyak responden yang memiliki personal hygiene yang baik akan tetapi memiliki pruritus vulvae yang sedang, hal ini juga dapat di lihat dari jawaban kuesioner yang di jawab oleh responden yang mengatakan ada yang selalu membersihkan alat kelamin dengan air yang mengalir akan tetapi hanya kadangkadang saja mengganti pembalut 4-5 kali dalam sehari pada saat menstruasi terjadi. Jadi walaupun salah satu aspek personal hygiene di lakukukan tetapi aspek yang lain jarang atau tidak di lakukan, akan memicu terjadinya pruritus vulvae. Hal ini sejalan dengan yang di katakan Hubaedah, (2019) dalam penelitiannya di katakan personal hygiene yang baik tidak menutup kemungkinan akan mendapat pruritus vulvae, karena pruritus vulvae dapat terjadi karena banyak faktor.

Responden dalam penelitian ini memiliti personal hygiene yang baik, akan tetapi Pruritus vulvae yang di dapatkan dalam penelitian ini dalam kategori sedang. Meskipun memiliki personal hygiene yang baik, pruritus vulvae yang sedang di dapatkan karena ada jawaban dari kuesioner responden ada yang menjawab selalu dan sering membersihkan vagina dengan sabun khusus pembersih vagina, akan tetapi hal ini sama saja karena dalam 
masalah personal hygiene harus semua aspek di penuhi. Banyak responden yang menjawab selalu dan sering membersihkan vagina dengan cara dari arah belakang ke depan. Hubaedah, (2019) mengatakan hal ini sangat tidak di anjurkan dalam membersihkan vagina, di karenakan dalam membersihkan vagina harus dari arah depan ke belakang, agar menghindari bakteri dari bagian anus masuk ke dalam vagina, yang dapat menyebabkan pruritus vulvae.

Dalam penelitian ini juga di dapatkan dari jawaban responden dalam kuesioner yang di bagikan, dapat di lihat bahwa pengetahuan akan cara membersihkan vagina dan pengetahuan untuk memakai sabun setelah selesai membersihkan vagina dari para responden sedikit kurang di buktikan dengan personal hygiene yang kurang memiliki pruritus vulvae yang berat sebanyak 12 responden (75,0\%) dan personal hygiene yang cukup memiliki pruritus vulvae yang berat sebanyak 8 responden $(23,5 \%)$. Hal ini dikarenakan kejadian pruritus vulvae saat menstruasi tidak hanya dipengaruhi oleh faktor pengetahuan saja, akan tetapi juga dipengaruhi oleh personal hygiene.

\section{SIMPULAN}

Dalam penelitian ini terdapat hubungan antara Personal Hygiene dengan Pruritus Vulvae, dimana semakin baik Personal Hygiene maka Pruritus Vulvae ada pada tingkat sedang.

Institusi Pendidikan diharapkan dapat digunakan sebagai sumber informasi dan acuan belajar mengajar yang berhubungan dengan Personal Hygiene saat menstruasi dengan kejadian Pruritus Vulvae. Bagi peneliti selanjutnya diharapkan untuk di kembangkan lagi dalam penelitian tentang Personal Hygiene dan Pruritus Vulvae.

\section{DAFTAR PUSTAKA}

Batubara.(2010). Adolescent Development (Perkembangan Remaja). https://www.researchgate.net/publi cation/312175400_Adolescent_De velopment_Perkembangan_Remaja . diakses 14 Agustus 2019

Depkes RI. (2015). Situasi kesehatan reproduksi remaja. Depkes.go.id

Depkes. (2001).Tindakan personal hygiene (vulvae hygiene) saat menstruasi pada siswi di Muhammadiyah $X$ Surabaya. 26 Agustus 2019

Hidayat. (2008).Pengantar Ilmu Kesehatan Anak untuk Pendidikan Bidan. Jakarta: EGC.

Hubaedah.(2019). Hubungan Pengetahuan Dan Perilaku Vulva Hygiene Saat Menstruasi Dengan Kejadian Pruritus Vulvae Pada Remaja Putri Kelas Vii Di Smp Negeri 1 Sepulu Bangkalan

Indah. (2012). Kejadian Pruritus Vulvae Saat Menstruasi pada Remaja Putri (Studi pada Siswi SMAN 1 Ngimbang Kabupaten Lamongan. Surabaya: Universitas Airlangga.

Kemenkes RI. (2017).Profil Kesehatan Indonesia Jakarta: Kemenkes RI

Kusmiran.(2012). Kesehatan Reproduksi Remaja dan Wanita. Jakarta: Salemba Medika

Nursalam.(2003). Konsep dan penerapan metodologi penelitian ilmu keperawatan. Jakarta: Salemba Medika

Pribakti .(2008). Tips \& Trik Merawat Organ Intim. Yogyakarta: Pustaka Banua

Priwirohardjo.(2014).Ilmu kebidanan. Jakarta: EGC

Riskesdas.(2016).Riset kesehatan dasar 2010. Badan penelitian dan 
pengembangan kesehatan
kementrian kesehatan RI

Riyanto.(2011). Metodologi Penelitian Pendidikan. Surabaya: SIC

Rosyid \& Mukhoirotin.(2017). Hubungan Perilaku Personal Hygiene Saat Menstruasi Dengan Kejadian Pruritus Vulvae

Solehati.(2017). Hubungan Sumber Informasi dan Usia Remaja Puteri dengan Perilaku Perawatan Diri saat Menstruasi

Sugiyono.(2006). Metode Penelitian Kuantitatif Kualitatif dan $R \& D$. Bandung: Alfabeta.

Sulaikha. (2018). Hubungan Personal Hygiene dengan kejadian Pruritus vulvae pada remaja

Wawan \& Dewi. (2010). Pengetahuan, Sikap, dan Perilaku manusia.Yogyakarta: Nuha Medika.

Wolff, Johnson. Fitzpatrick's. (2009). Color atlas and synopsis of clinical dermatology. Edisi ke-6. New York:McGraw Hill; 73-86 